\title{
Biomass residues for energy production and habitat preservation. Case study in a montado area in Southwestern Europe
}

\author{
I. Malico ${ }^{\text {a, b, }}{ }^{*}$, J. Carrajola ${ }^{\text {a }}$, C. Pinto Gomes ${ }^{\text {a }}$, J.C. Lima ${ }^{c}$ \\ ${ }^{a}$ Universidade de Évora, R. Romão Ramalho, 59, 7000-671 Évora, Portugal \\ ${ }^{\mathrm{b}}$ LAETA, IDMEC, Instituto Superior Técnico, Universidade de Lisboa, Av. Rovisco Pais 1, 1049-001 Lisboa, Portugal

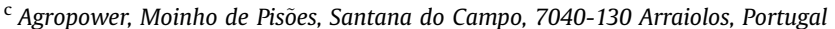

\section{A R T I C L E I N F O}

\section{Article history:}

Received 19 February 2015

Received in revised form

9 July 2015

Accepted 26 July 2015

Available online 1 August 2015

\section{Keywords:}

Bioenergy

Residual biomass

Energy potential

Heating systems

Preservation of ecosystems

Montado

\begin{abstract}
A B S T R A C T
The use of forest and agricultural residues for energy production presents multiple benefits, but the link between bioenergy and the environment is complex and not all of the energetic options have the same impacts. This work evaluates the net positive effect of valorizing residual biomass in the context of a rural area of Portugal, Estremoz. It focuses on the combined assessment of biomass availability, technoeconomic feasibility and environmental aspects of utilizing forest and agricultural residues to produce bioheat. At first, the energy potential of the residual biomass available in the municipality is evaluated using a geographical information system database. The assessment with RETScreen of the technoeconomic feasibility of replacing electricity by biomass for heating local public schools follows. The results show that around 27314 t of residues, corresponding to about $267680 \mathrm{GJ}$, are produced each year in Estremoz, more than half in montado areas. The use of this biomass for the replacement of the existing electric heating systems of nine local schools by biomass-based ones offers good project profitability. As far as the environment is concerned, the energetic valorization of the residual biomass in Estremoz has multiple benefits. It contributes to climate change mitigation by saving greenhouse gas emissions and promoting the preservation of the traditional extensive uses of the ecosystems. Moreover, a correct vegetation management decreases the fire risk, potentiates the increase in biodiversity, offers better conditions for native species and allows to maintain the ecosystems.
\end{abstract}

(C) 2015 Elsevier Ltd. All rights reserved.

\section{Introduction}

Europe 2020 strategy aims at, among others, creating a sustainable and growing low-carbon economy by improving energy sustainability and preventing climate change (EC, 2010). To reach this goal, the promotion of renewable energies is of upmost importance, being bioenergy, particularly wood and wood waste, expected to make a key contribution (EC, 2014).

When compared to fossil fuels, biomass can help to reduce direct greenhouse gas emissions (GHG); however, its implications for the whole life cycle are less clear (Jeswani et al., 2011). The impacts of biomass removal from the environment vary in nature and extent according to the production system used (Lattimore

\footnotetext{
* Corresponding author. Universidade de Évora, R. Romão Ramalho, 59, 7000-671 Évora, Portugal. Tel.: +351 266745 372; fax: +351 266745394 .

E-mail addresses: imbm@uevora.pt (I. Malico), joao.cbc@hotmail.com (J. Carrajola), cpgomes@uevora.pt (C.P. Gomes), joao.lima@agropower.pt (J.C. Lima).
}

et al., 2009) and introduce trade-offs with other ecosystem services (e.g., Harrison et al., 2014; Makkonen et al., 2015). Several authors analyzed the potential negative environmental effects of bioenergy. Some non-exhaustive examples are presented next Lattimore et al. (2009) systematically reviewed the environmental risks that can be encountered in forest biomass harvesting and production systems. Verkerk et al. (2014) investigated the biophysical and economic impacts of increased forest biomass production for bioenergy and biodiversity protection on forest ecosystem services in Europe and concluded that larger benefits would be obtained if forest biodiversity protection is enhanced. Jeswani et al. (2011) evaluated the environmental impacts and economic costs of co-firing with coal different types of biomass (miscanthus, willow and waste fuel) and concluded that waste wood appears to be environmentally the most sustainable option. González-García et al. (2014) arrived at a similar conclusion. These authors performed a comparative life cycle assessment study and demonstrated that the utilization of biomass residues (vineyard pruning and eucalypt logging residues) for energy production is 
environmentally beneficial and has a lower impact than using wooden energy crops (poplar).

In their study, González-García et al. (2014) also pointed out that further analysis should focus on the availability of biomass sources for energy purposes. The same need was recognized by Lourinho and Brito (2015), who identified the lack of knowledge on the resource potential as one of the key barriers to biomass development. Also, Gómez et al. (2010b) referred that accurate estimates of biomass sources are needed in order to support policy decisions. Several studies have estimated the potential of different agricultural and forest residues available for energy purposes in several regions of the world (e.g., López-Rodríguez et al., 2009; Gómez et al., 2010a; Scarlat et al., 2011; Monforti et al., 2013). Worth mentioning is the fact that estimates for the same area and biomass category may present relevant differences (see, for example, Monforti et al., 2013). A review of the studies on the assessment of residual biomass in Portugal follows, since this is the regional scope of our work.

The bioenergy potential for Portugal has been assessed in several works (Ericsson and Nilsson, 2006; Ferreira et al., 2009; de Wit and Faaij, 2010), revealing that there are still untapped biomass resources in the country. Adding to these studies, others with a more specific and/or regional scope have also been published for the country. For example, Viana et al. (2010) determined Portugal's forest biomass resource potential for the commercial generation of electricity. They focused on maritime pine and eucalyptus stands. In another study, Fernandes and Costa (2010) presented an evaluation of the potential of biomass residues in the municipality of Marvão, a region in the east of the country, where cork and holm oaks have an important presence. They used geographical information system (GIS) database and statistical analysis to achieve this task, along with a thermal energy utilization case study. More recently, Lourinho and Brito (2015) determined the biomass energy potential in a larger region, where Marvão is included. They also used GIS as a supporting tool.

Less common in the literature are the works that integrate the assessment of the residual biomass potential for energy production with techno-economic feasibility analyses and with the environmental aspects of bioenergy projects. Examples of studies where the agricultural or forest waste-to-energy potential and economic analysis are integrated are the ones by Boukis et al. (2009), Fernandes and Costa (2010) and Gómez et al. (2010b); while in Skoulou and Zabaniotou (2007), the environmental aspects are also taken into account.

From all of the above we highlight that: $i)$ quantifying the energy potential of biomass resources at local level is important and needed; $i i)$ there is a complex link between bioenergy and the environment and iii) using agricultural and forest waste streams seem to be a good choice as far as environmental impacts are concerned. Having this in mind, this study addresses the impacts of residual biomass utilization in the context of a rural region in inland Portugal, the municipality of Estremoz. In a first step, the available residual biomass potential in Estremoz is assessed and its possible energy use quantified. A feasible scenario for the conversion of this biomass into heat is then proposed and its financial viability analyzed. With the first part of the paper, we intend to quantify the untapped biomass potential in the region, which can be used with multiple benefits. Following this case study, the relation between biomass energy utilization and ecosystems management and preservation is discussed.

\section{Description of the Estremoz region}

The Estremoz municipality occupies an area of $514 \mathrm{~km}^{2}$, belongs to the Évora district and is located in the eastern part of Portugal.
The latitude of its main city, also called Estremoz, is $38^{\circ} 50^{\prime} 34.29^{\prime \prime} \mathrm{N}$ and the longitude $7^{\circ} 35^{\prime} 10.50^{\prime \prime} \mathrm{W}$. It is mainly a rural region that suffers from a common problem to most of the regions in inland Portugal: human desertification (INE, 2011). The municipality is characterized by wide daily and seasonally temperature ranges (the average temperatures are around $10{ }^{\circ} \mathrm{C}$ and $23{ }^{\circ} \mathrm{C}$ in winter and summer, respectively) and by rainy and dry seasons (Mendes et al., 1991). Most of the region consists of hilly terrain with moderate slopes (CME, 2010).

The relevance of studying the Estremoz municipality is related to: $i)$ first of all, the fact that it is a rural region with a high depopulation and land abandonment, and thus with competitive inequality. In this context, it is crucial to define new strategies to invert this tendency; ii) secondly, non-valorized forest and agricultural residues are available in Estremoz. These residues could be economically interesting for the development of this region; iii) additionally, the territory has significant ecological values. Defining lines of action that can be both helpful for biodiversity conservation and for the economic and social development of this territory is important. It should be mentioned that the territorial and ecological values of the Estremoz region are common to several other areas of the Iberian Peninsula. In this sense, the conclusions drawn in this study should not be analyzed as restricted to the municipality, but have a wider territorial scope.

\section{Methods}

This study followed three major steps. To begin with, the availability of residual biomass generated by forest and agricultural activities in Estremoz was determined. This allowed for the determination of the energy potential of residual biomass available in the region. After this first step, a case study was used with the objective of demonstrating the financial viability of utilizing biomass residues for energetic purposes in the study area. In the final step, the relationship between habitat preservation and biomass energy valorization is discussed in the context of the Estremoz region.

\subsection{Determination of the energy potential}

For the determination of the biomass energy potential from agricultural and forest residues, geographical information on land cover was fed into a GIS environment and used to calculate the areas occupied by each forest and agricultural species within the boundaries of the municipality. Each of this area was then multiplied by the residue productivity of the respective forest or agricultural biomass family in order to obtain the theoretical yearly amount of residues that it produces. This quantity was converted into energy using the lower heating value of the species $(14 \mathrm{GJ} / \mathrm{t}$, according to Fernandes and Costa (2010)) and considering a thermal conversion efficiency of $70 \%$ (the same value was used by Vieira et al. (2006) and Fernandes and Costa (2010) for the biomass conversion into bioheat through combustion technologies).

The land cover map of Estremoz used was the CORINE Land Cover map from 2006, which is a vector map with a scale of $1: 100000$, a minimum cartographic unit of 25 ha and a geometric accuracy better than $100 \mathrm{~m}$ (EIONET, 2014). Note that in the Estremoz region, the landscape in not fragmented and $91 \%$ of the utilized agricultural area has more than 20 ha (INE, 2012), an area close to the minimum cartographic unit of the map. The CORINE Land Cover 2006 map of Continental Portugal was produced by the Remote Sensing Unit of the Portuguese Geographic Institute and its estimated overall accuracy is $90.2 \%$, with an absolute precision of 1.3 at the 95\% confidence level (APA, 2014). Based on the data of the CORINE Land Cover map, the areas of each of the ecosystems that 
are relevant in the study area were determined using GIS. Additionally, for the montado, data from the City Council was utilized in order to distinguish the areas that are covered with cork and holm oaks (CME, 2010).

A first analysis of the land cover suggests that a considerable part of the Estremoz territory can be exploited for residual biomass energy valorization. In our opinion, the areas of olive grove (small group of olive trees, Olea europaea L.), montado, vineyard, scrubland (sclerophyllous shrubs), gardens and parks are particularly interesting because of the amount of residues they produce or for environmental reasons as explained in the discussion section.

The montado with evergreen Quercus spp., which corresponds to habitat 5330 from Nature 2000 network included on the 92/43/EEC Directive, covers important areas of the municipality (CME, 2010). It is a threatened forest-grazing ecosystem of high socioeconomic and conservation value (Pinto-Correia and Godinho, 2013; PintoCorreia et al., 2013). Used primarily for grazing, the montado is a multifunctional system that can provide many commercial (e.g., livestock, cereals, cork, game, honey, firewood and charcoal) and non-commercial (e.g., scenic value, carbon storage, biodiversity, soil conservation and recreation) goods and services. Its main forest tree species are the cork oak (Quercus suber L.) and the holm oak (Quercus rotundifolia Lam.). For a detailed characterization of this ecosystem, which is known as dehesa in Spain, see, for example, Joffre et al. (1999) and Canteiro et al. (2011).

The sclerophyllous shrubs are a natural type of vegetation, dominant in the thermo-Mediterranean and semi-arid zones, although they can exist on dry and sub-humid ombrotypes, namely on eroded soils. They are mainly Cisto-Lavanduletea shrublands, which are dominated by Cistaceae (e.g., Cistus ladanifer) and Labiatae (e.g., Lavandula Sect. stoechas), known as garrigue, and woody shrublands dominated by Quercus coccifera, Olea sylvestris and Arbutus unedo, known as maquis. Those are secondary shrub communities, resulting mainly from fire destruction of natural potential sclerophyllous forests ( $Q$. suber and $Q$. rotundifolia woodlands), as well as wood cuttings and subsequent erosion of the upper layer of the soils (Rivas-Martínez, 1979). They correspond to habitat 5330 from Nature 2000 network included on the 92/43/EEC Directive.

The philosophy behind this study was to valorize residual biomass obtained from pruning and maintenance of biomass species; therefore biomass specifically produced for energy purposes was not considered. According to some studies, energy crops constitute the largest biomass potential in Europe (Ericsson and Nilsson, 2006; de Wit and Faaij, 2010). If our sole goal was to produce bioenergy, we could have proposed the conversion of forest and/or agricultural land into energy crop production. However, the growing of energy crops raises a number of questions and there is an intense debate about the production of energy crops. Some possible risks of energy crops are the competition with food and feed crops for land use, deforestation and the consequent negative impact on climate change, the introduction of competitive invasive species with an impact on biodiversity and the increase of NO emissions due to high levels of fertilization. Bringezu et al. (2009) discuss the global implications of biomass and biofuel use in Germany and conclude that by-products and organic wastes should be used for energy production. Another study by Anderson and Fergusson (2006) considers the major impacts of using biomass as fuels on biodiversity. They state that wood biomass generated by traditional management techniques may result in biodiversity benefits, whereas dedicated biomass crops grown in lands that used to be less intensively managed are more likely to have negative effects on overall biodiversity.

Having this in mind, the potential yearly amount of biomass from forest and agricultural activities in the Estremoz municipality was calculated, considering the residue production yields of each species. These yields were obtained from studies with a comparable geographical location (Vieira et al., 2006; Fernandes and Costa, 2010; Gómez et al., 2010a). An exception to this procedure was the determination of the quantity of the residual biomass collected in gardens and parks. In this case, the yearly biomass production was estimated from the information on the available amount of residues given by the City Council, which is responsible for its collection (Rui Franco, personal communication, 2013).

An analysis of the literature showed that relevant differences are sometimes found in the estimates for the residue production yields. This differences can be justified in part due to the fact that residue yields are very variable and depend on several factors, such as plant variety, climate and soil condition or management strategies. This variability introduces an uncertainty in the calculations that need to be considered. Adding to this, biomass losses take place in the extraction, transportation and storage activities, resulting in a lower biomass availability for energy. For example, González-García et al. (2014) report biomass loses of 6\% in a French vineyard.

\subsection{Case study for energy utilization}

With the sole goal of verifying that the energy valorization of the residual biomass available in Estremoz is economically viable, we have chosen one suitable case study scenario. We could have analyzed and compared different conversion technologies and energy uses, as for example Gómez et al. (2010b), but such a study was beyond our objectives. The results obtained from specific case studies are able to provide valuable insight into real life projects involving decision making. However, one of the limitations of using a case study approach is that the results presented are only valid for the specific scenarios analyzed and cannot be generalized.

Among the several possibilities, we chose to study the technoeconomic feasibility of heating the public schools located in the municipality. We decided to focus on decentralized bioheat production, because biomass is a geographically distributed resource and often the costs associated with its transport are high (de Wit and Faaij, 2010). This economic (but also environmental) constraint points to the energetic valorization of biomass in systems that are relatively small and close to the place where biomass is produced. Worth mentioning here is the study by Lourinho and Brito (2015) on the biomass energy potential in a region with $6084 \mathrm{~km}^{2}$ close to Estremoz (Estremoz is approximately 12 times smaller). These authors concluded that local biomass would only meet $45 \%$ of the biomass requirements of a $9 \mathrm{MW}$ biomass power plant planned for the region. They examined alternative solutions to this power plant and stated that decentralized small scale production units for heat production constitute an interesting and even desirable option. Within this framework, we could have analyzed the utilization of biomass in households, hotels, public buildings, etc. We selected the public schools of the municipality as our case study, because local authorities could and should be an important drive for the promotion of energy efficiency measures and the replacement of conventional uses of energy by renewable energies. The schools are public buildings that can be used for attaining these purposes.

The bigger schools in Estremoz already use solar energy for heating; therefore, they were not included in the analysis. The remaining nine smaller schools of the municipality are heated with electricity, are characterized by a poor building thermal performance and have heated floor areas ranging from $96 \mathrm{~m}^{2}$ to $384 \mathrm{~m}^{2}$. All of them have the same building typology because they are integrated in the Plano dos Centenários campaign for the construction of elementary schools in Portugal (Carlos and Corvacho, 2010). Since the schools that have the same number of rooms have identical floor plans and building characteristics, they have been 
clustered in groups according to the number of rooms. Four groups were formed: three schools have two rooms and a heated floor area of $96 \mathrm{~m}^{2}$, two schools have three rooms and a heated floor area of $144 \mathrm{~m}^{2}$, two schools have four rooms and a heated floor area of $192 \mathrm{~m}^{2}$, and the remaining two schools have eight rooms and a heated floor area of $384 \mathrm{~m}^{2}$ (see Table 2).

Feasibility studies for the replacement of the current heating systems based on electricity by biomass-based heating systems were performed using RETScreen 4 (RETScreen, 2013). The "RETScreen Clean Energy Project Analysis Software" is a tool that helps to determine the technical and financial viability of potential renewable energy, energy efficiency and cogeneration projects. It is developed and maintained by the Government of Canada and supported by an international network of partners. Some examples of the use of RETScreen for the evaluation of biomass projects are Chalikias et al. (2010), Mani et al. (2010) and Mallaki and Fatehi (2014).

Currently, most of the nine schools use simple and relatively cheap electrical heaters, while others use air conditioning systems. Since the cost of the electricity currently consumed is $0.139 €$ $\mathrm{kWh}^{-1}$, the heating costs are high. We propose to replace the utilization of the electrical heaters by biomass systems that would burn the residual biomass obtained from the Estremoz's region. The lifetime of the biomass system was considered to be 30 years. It was assumed that this biomass would cost $28 € \mathrm{t}^{-1}$ (equal to the ex factory price of wood chips in Portugal) and that the annual maintenance cost of the biomass system would be $200 €$ year $^{-1}$. The discount rate used was simply the inflation rate in the country for 2012, which was considered to be $2.8 \%$ (Eurostat, 2014). It was also assumed that no debt is incurred in order to make the investment in the biomass heating system.

\section{Results}

\subsection{Potential of biomass residues for energy production}

Table 1 presents the areas covered by the most important biomass sources in Estremoz obtained from the CORINE Land Cover map. It also shows the yearly production of residues and the potential of energy production for each of the waste streams considered.

It can be seen from Table 1 that cork oak and holm oak cover a significant area of the Estremoz municipality, which by itself makes them interesting for energy valorization. There is presently some demand in the region for cork oak and holm oak wood, mainly to be used in fireplaces and for the production of charcoal. However, to the best of our knowledge, this demand is not quantified and there is no data on the percentage of cork oak and holm oak wood residues that are valorized in Estremoz. In the Algarve, a region relatively close to Estremoz and where the montado is also important, most of the forest owners do not valorize the cork oak and holm oak wood residues they produce, and the ones that do it, use them for self-consumption only (MAOTDR, 2006).
Table 1 shows that olive trees plantations and vineyards are also present in Estremoz, but in a smaller extent. Despite the lower cover areas, the residues they produce are also interesting for energy valorization, given their high production yields and the fact that this wood is not usually valorized, but mainly left in the soil to decay or piled and burned in the fields. In a recent study, Picchi et al. (2013) compared the combustion of vineyard pruning residues and wood chips, proving the former are a suitable fuel for combustion in small scale boilers. It should be emphasized that vineyard residues are particularly interesting due to their high production yields. Owing to this characteristic, a large amount of residual biomass can be obtained from a relatively small area, facilitating its collection, optimizing the logistic involved and, therefore, making them very interesting for energy valorization. Furthermore, in Estremoz, the vineyard areas are situated very close to the more populated regions of the municipality, and, therefore, to the potential biomass consumption sites.

As far as the sclerophyllous shrubs are concerned, their elimination and subsequent energy valorization is proposed in this study above all to prevent wildfires. Their ecological importance is not high and their removal does not harm the habitats. The total area covered by sclerophyllous shrubs in Estremoz ( $550 \mathrm{ha}$ ) is small and at a first glance not worthy of particular relevance. However, this kind of vegetation is very dynamic and can establish itself in two or three years, if an ecosystem is abandoned or not managed (Cammeraat and Imeson, 1999). Note that this study did not consider the removal of heliophilous shrubs for energy purposes. Among other reasons, they are important due to the positive effects of their interaction with seedlings of tree species (Alias et al., 2010). This fact is particularly important in an ecosystem with low rates of natural regeneration such as the montado.

Lastly, garden and park wastes were included in the analysis, not because of their volume, but because they are already collected by the City Hall but not valorized (they are either sent to a landfill or burned in open air). It is a much better environmental option to valorize them.

After considering the different residual biomass sources, Table 1 shows that for the Estremoz municipality, the yearly production of forest and agricultural residues is $27314 \mathrm{t}$, corresponding to a yearly energy potential of $267680 \mathrm{GJ}$. If one considers that the total amount of residual biomass generated in Estremoz would be used for heat production, this would result in an availability of $14 \mathrm{kWh}_{\mathrm{t}}$ day $^{-1}$ inhabitant ${ }^{-1}$. This result was obtained by dividing the total energy potential presented in Table 1 by the number of inhabitants in the Estremoz municipality, which is 14298.

\subsection{Case study for biomass utilization}

Table 2 shows the most important results of the technoeconomic studies performed for the nine public schools presented earlier. Using RETScreen, the yearly energy needed for heating the schools was calculated, alongside with the power requirements of both the proposed biomass and current electricity

Table 1

Cover area, production yield, yearly production and energy potential for each of the residues considered.

\begin{tabular}{|c|c|c|c|c|}
\hline Biomass source & Area [ha] & Production yield [dry t/ha/year] & Biomass production [dry t/year] & Energy potential [GJ/year] \\
\hline Cork oak & 10156 & $1.00^{*}$ & 10156 & 99529 \\
\hline Holm oak & 8760 & $0.48^{*}$ & 4205 & 41207 \\
\hline Olive trees & 5059 & $1.50^{*}$ & 7589 & 74367 \\
\hline Vineyard & 1426 & $2.19^{\#}$ & 3123 & 30605 \\
\hline Scrubland & 550 & $4^{\$}$ & 2200 & 21560 \\
\hline Garden/Park & - & - & 42 & 412 \\
\hline Total & 25951 & - & 27314 & 267680 \\
\hline
\end{tabular}

Estimates obtained from ${ }^{\$}$ Vieira et al. (2006), ${ }^{*}$ Fernandes and Costa (2010) and ${ }^{\#}$ Gómez et al. (2010). 
Table 2

Characteristics and financial, cost and emission analyses of the four scenarios for the replacement of the electric heating systems by biomass heating.

\begin{tabular}{|c|c|c|c|c|}
\hline & School type I & School type II & School type III & School type IV \\
\hline Number of schools & 3 & 2 & 2 & 2 \\
\hline Heated floor area $\left[\mathrm{m}^{2}\right]$ & 96 & 144 & 196 & 384 \\
\hline Number of rooms & 2 & 3 & 4 & 8 \\
\hline Total heating $\left[\mathrm{MWh}_{\mathrm{t}} / \mathrm{year}\right]$ & 11 & 17 & 23 & 45 \\
\hline Power of the biomass system [kW] & $13-18$ & $13-30$ & $13-30$ & $13-30$ \\
\hline Biomass system capital cost $[\mathrm{k} €]$ & 12.8 & 13.3 & 13.3 & 13.3 \\
\hline Wood chips consumption [t/year] & 4 & 6 & 7 & 15 \\
\hline Biomass cost $[€ /$ year $]$ & 112 & 168 & 196 & 420 \\
\hline Electricity costs avoided [k€/year] & 1.3 & 2.0 & 2.6 & 5.2 \\
\hline Simple payback [year] & 12.8 & 8.3 & 6.0 & 2.9 \\
\hline $\mathrm{NPV}[\mathrm{k} €]$ & 32.0 & 57.0 & 82.3 & 184.2 \\
\hline IRR $[\%]$ & 12.5 & 17.5 & 22.5 & 41.5 \\
\hline GHG emissions savings [ $t_{\mathrm{CO} 2} /$ year] & 4.6 & 6.9 & 9.2 & 18.4 \\
\hline
\end{tabular}

systems. Based on these results, biomass boilers that are available on the market were chosen (their powers are also specified in Table 2). The biomass system cost (boiler, accumulator, pipes, radiators, etc.) was estimated based on the prices obtained from the suppliers of the equipment.

Table 2 shows that using biomass is less costly than utilizing electricity for heating the nine schools. We can conclude that the replacement of the actual electrical heating systems by biomass offers, in all cases, a good project profitability, especially for the bigger schools. The payback periods range from 3 to 13 years, the net present value (NPV) from 32 to $184 \mathrm{k} €$ and the internal rates of return (IRR) from 13 to $42 \%$.

Biomass projects are dependent on site, fuel, supply systems, conversion technology and energy use, therefore their economic evaluation does not result in some general norm and a comparison between studies is difficult. Techno-economic viability studies of residues-to-bioheat projects are scarce. Fernandes and Costa (2010) studied the economic viability of replacing the two gas oil boilers of a heating system of a small hotel in Marvão by a $50 \mathrm{~kW}$ pellets heating system. They concluded that the proposed conversion to the biomass-based system would have economic and environmental advantages. They estimated a payback period of 3.4 years, a little bit higher than the 2.9 years payback we obtained for the bigger schools in Estremoz (note that pellets are costlier than wood chips). In another study, Michopoulos et al. (2014) studied the economic benefits of using residual biomass instead of diesel oil for building space heating in Greece. They concluded that significant financial benefits for the end-user could result from this substitution. Depending on the fuel type and geographical region, the payback period ranged from 1.1 to 8.7 years. The lower values of the payback correspond to the scenarios where the demand for heat is bigger, like in the present study.

If the projects were implemented in all of the nine schools, this would mean a consumption of $68 \mathrm{t}$ residual biomass per year and yearly GHG savings of around $80 \mathrm{t}$ (values obtained from Table 2). It can be seen that the schools would only absorb a small part of the biomass potential of the region. The rest of the residual biomass produced in the region could be sold to other local consumers. Once again, the municipality could be an important drive for the installation of biomass systems, but also private companies and homes could be potential investors.

Seasonality can be an important constraint for the energetic valorization of biomass, especially for agricultural residues as it is the case of this work (Alfonso et al., 2009). If we take into account the pruning season of each species, the monthly availability of all the residues accounted for in Table 1 can be determined (see Fig. 1). Scrub elimination was considered to take place in summer, when wildfires are more likely to happen and after the breading season ends. From Fig. 1, we can see that the seasonality of the heating requirements for the schools is in phase with the biomass availability (residual biomass is mainly produced in the colder months).

\section{Discussion}

\subsection{General discussion}

The results presented in this study show that: $i$ ) a potential to valorize the residues produced in the agricultural and forestry sectors in Estremoz exists and that ii) it is economic viable to replace the existing electric heating systems of nine public schools in Estremoz by biomass-based heating system.

As far as the logistic structure needed to valorize biomass residues in Estremoz is concerned, it should be said that the road network is good, the slopes moderate and that the travelled distances from the biomass collection site to an end or intermediate use site in the municipality are not big. The average distance between the civil parishes and the City Hall is $11 \mathrm{~km}$ (CME, 2008). These three facts reduce the costs associated with transport.

If one wants to implement an energy valorization project such as the one proposed in this study, it is essential that the landowners in the municipality are contacted and made sensitive to the energetic valorization of their residues. One thing that makes this task apparently easier is the fact that the mean area of the properties in Estremoz is high (According to INE (2012), more than $80 \%$ of the holdings have more than 50 ha). In fact, this is a characteristic of the areas of montado in the Iberian Peninsula, and not only of Estremoz:

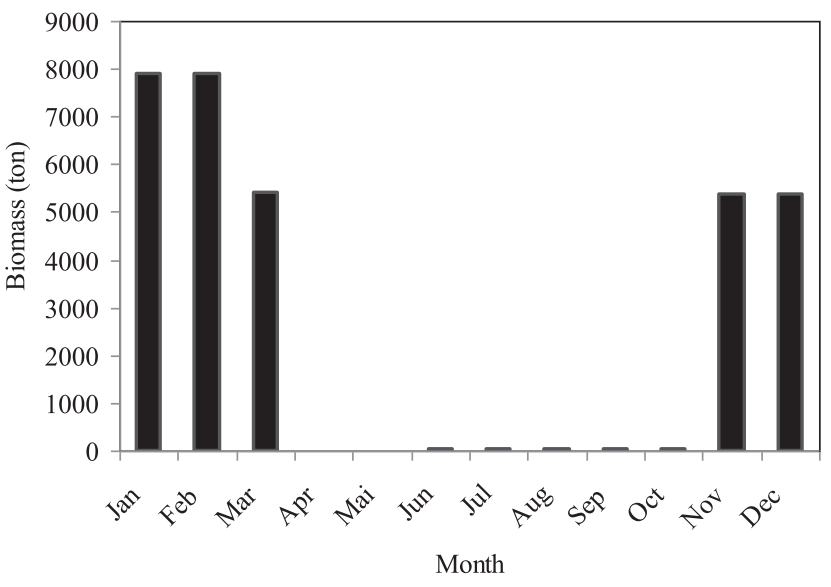

Fig. 1. Seasonality of the residual biomass in Estremoz. 
the ownership is characterized by large private estates called latifúndios.

\subsection{Climate change implications}

If $68 \mathrm{t}$ of residual biomass was used as bioheat in the nine public schools and the remaining biomass was used for household heating, the emission of $2.2 \mathrm{t}_{\mathrm{CO} 2}$ year $^{-1}$ inhabitant $^{-1}$ would be avoided. This value was obtained applying RETScreen for an average house in Estremoz, which has a floor area of $67.2 \mathrm{~m}^{2}$ (CME, 2008) and that would save $3.2 \mathrm{t}_{\mathrm{CO} 2}$ year $^{-1}$ if an electrical heating systems would be replaced by a biomass heating system. In this estimation, all the other parameters were assumed to remain equal to the ones used in the case studies presented above.

These results are just rough estimates, but show the impact of locally valorizing residues from agriculture and forestry for energy. Projects that involve the energetic valorization of forest or agricultural residues usually result in savings of GHG emissions above $70 \%$ if used to substitute fossil energy (EC, 2014). In this way, they are one of the existing mechanisms for climate change mitigation. Another climate change mitigation mechanism that also relies on the functions of ecosystems is the management of wood for carbon sequestration. Through this mechanism, plants absorb $\mathrm{CO}_{2}$ from the atmosphere and store it in the existent biomass above ground or in the soil (Makkonen et al., 2015). A fundamental trade-off between these two mechanisms exists. The best is that these two ecosystem services (wood for energy production and carbon storage) are synergistic and that together they originate the largest sustainable mitigation benefit. If the preservation of the traditional extensive agro-forestry systems in Estremoz is promoted, and the montado is properly managed, benefits can be obtained both in terms of bioenergy and carbon storage.

\subsection{Benefits of residual biomass valorization for ecosystems preservation}

Efforts to preserve biological diversity should be increasingly directed to ecosystems preservation rather than species, although constant concern with species is crucial (Franklin, 1993). Considerable efforts have been focused on preserving pristine environments, but biodiversity conservation also involves areas where human activities are important (Bélair et al., 2010). The ecosystems affected by man that present a high ecological value should not be forgotten. Natural resource management techniques can proactively change the context in which ecosystems develop, help fighting the biodiversity reduction and increase ecosystems resilience, which helps on climate change mitigation. Additionally, several ecosystems, where forest ecosystems are included, are active $\mathrm{CO}_{2}$ sinks and therefore contribute to the mitigation of climate change (Schimel et al., 2001).

The ecological implications of valorizing the residual biomass in Estremoz are explored in the next paragraphs. Only biomass residues from the agricultural and forestry activities and biomass from sclerophyllous scrubs were considered for energy production. The reason for including the latter is related to conservation reasons. The correct vegetation management through the elimination of sclerophyllous shrubs (e.g., Cistus spp., scrublands and Erica spp. heathlands) not only allows for the energetic valorization of this biomass, but has also the advantage of reducing the fuel load present in the ecosystem. This decreases the fire risk, potentiates the increase in biodiversity and offers better conditions for the native species (such as Narcissus fernandesii G. Pedro, a species of special interest for conservation under the EU Habitat Directive). A correct vegetation management in the Estremoz region does not only favour single species, but also allows to maintain entire ecosystems (namely, habitat 6310 - montado with evergreen Quercus spp., considered in the EU Habitat Directive as a natural habitat of community interest whose conservation requires the designation of special areas of conservation, and habitat $6220^{*}$ - the pseudosteppe with grasses and annuals of the Thero-Brachypodietea, also a priority habitat type under the same directive). Note that the shrubs control should be permanently made by cutting (never destroying the soil structure). This will encourage the conservation of species with patrimonial value that normally are associated to conserved soils.

From all the existent ecosystems in the Estremoz municipality, the montado with evergreen Quercus spp., 6310, is the one that covers the most area. It should be said that holm oak and cork oak trees are naturally distributed around the Western Mediterranean basin and the montado dominates not only the region studied in this paper, but also the landscape of the southern Iberian Peninsula, being in general threatened. In order to manage this and any other ecosystem, one needs to know its conservation status. Nowadays, the montado presents some areas of high oak mortality, being diseases and plagues, oak ageing, lack of regeneration and fires the major threats. From these, the absence of tree regeneration poses the most important problem (ICNF, 2013). Threshold grazing levels for successful regeneration are probably low, and additional human impacts on vegetation, in particular regular brushing and soil tillage, seem to be important barriers to oak regeneration (Plininger et al., 2004).

Farmers lack interest in the montado, especially in the holm oak areas, and the system profitability is low (Plininger et al., 2004). According to Campos et al. (2008), the montado is not sustainable under current management and, in light of the current land use policy incentives, it is more cost-effective for a private landowner to allow for the slow conversion of the montado into pasture and scrubland than to maintain the oak trees and to invest in the oak natural regeneration and restrict grazing.

The human abandonment of the montado is also a possible outcome (with an opposite effect) in a region that is losing population. Although the complete abandonment of the montado is rare, the extensification of the land use observed in some of the areas also leads to a loss of the system balance (Pinto-Correia and Mascarenhas, 1999). This extensification is a result, for example, of different uses of the montado, such as hunting or rural tourism (Pinto-Correia and Mascarenhas, 1999) or of the fact that the montado has become a luxury asset where investors accept low commercial profitability rates against the personal consumption of the estates' amenities (Campos et al., 2008). The extensification of the montado can lead to its conversion into $Q$. suber forests (habitat 9330) or Quercus ilex and Q. rotundifolia forests (habitat 9340). According to the montado's preservation objectives stated in the Natura 2000 network sectorial plan (ICNF, 2013), it is acceptable that $30 \%$ of its occupation area is converted into habitats 9330 and 9340. If this management option is followed, the sclerophyllous shrubs should be controlled and could be used for energy production. The simple abandonment of the montado, with no elimination of shrubs, is not recommended since the fire risk increases. Land cover is one of the important factors that influences fire spread and the management of vegetation structure and fuel loads is directly linked to fire patterns (Moreira et al., 2011).

Although converting $30 \%$ of the montado into other ecosystems is acceptable, the remaining area should be preserved according to the Natura 2000 network sectorial plan. Since it is expensive to maintain the traditional uses of the montado, its sustainability can only be achieved through the development of new services and products. Promoting the energy use of oak wood residues is one of the ways to achieve this, but care has to be taken not to overexploit the wood resources. Certainly, increasing environmental risks 
associated with a more intensive forest management exist and guidelines for sustainable forest management for wood fuel production should be followed (see for example, Lattimore et al. (2009)). Additionally, it is essential to manage the grazing pressure in the montado and to control scrubs that can and should be used for energy purposes.

\section{Conclusions}

This paper presents a combined assessment of the biomass availability, the techno-economic feasibility and the environmental aspects of utilizing forest and agricultural residues to produce bioheat in a rural area in Portugal, Estremoz. The main conclusions of this investigation are summarized below:

- Around 27314 dry t of residues, corresponding to about $267680 \mathrm{GJ}$, are produced each year, more than half in montado areas. This ecosystem is the predominant in Estremoz and presents a high ecological and cultural value.

- There are still untapped biomass resources in Estremoz that could be valorized.

- The replacement of the existing electric heating systems of nine schools in the Estremoz municipality by biomass-based ones offers good project profitability. The payback periods of the investment range from 3 to 13 years, increasing with a decrease in the heating demand. The NPV are positive and range from 30 to $178 \mathrm{k} €$ and the IRR from 13 to $42 \%$.

- The implementation of biomass heating systems in the nine schools would result in yearly GHG savings of $80 \mathrm{t}$. If other biomass projects would be implemented, the savings would be higher.

- The energetic valorization of the residual biomass would offer an additional income to the landowners, valuing the biomass that would otherwise be pilled and burned in open air with no major benefit.

- The extensive forest uses in Estremoz, namely the montados, should be preserved and properly managed, so that they can originate the largest sustainable climate change mitigation benefit (in terms of carbon storage and bioenergy).

- A correct vegetation management, for example through the removal of the sclerophyllous shrubs, decreases the fire risk, potentiates the increase in biodiversity, offers better conditions for native species and allows to maintain the ecosystems.

The results of the present study are important to support policy decisions and to establish guidelines for bioenergy projects. Additionally, it highlights the benefits that arise from properly managing the montado, an ecosystem that provides many benefits to the society. Even though the study was focused in Estremoz, Portugal, similar ecosystems are naturally distributed around the Western Mediterranean basin.

\section{Acknowledgements}

We would like to thank Rui Franco from the Estremoz City Council for his collaboration. Isabel Malico would like to thank Fundação para a Ciência e Tecnologia (Project UID/EMS/50022/ 2013).

\section{References}

Alfonso, D., Perpiñá, C., Pérez-Navarro, A., Peñalvo, E., Vargas, C., Cárdenas, R., 2009 Methodology for optimization of distributed biomass resources evaluation, management and final energy use. Biomass Bioenergy 33 (8), 1070-1079. http://dx.doi.org/10.1016/j.biombioe.2009.04.002.
Alias, S., Bianchi, L., Calamini, G., Gregori, E., Sioni, S., 2010. Shrub facilitation of Quercus ilex and Quercus pubescens regeneration in a wooded pasture in central Sardinia (Italy). iFor. Biogeosci. For 3 (1), 240-245. http://dx.doi.org/10.3832/ ifor0517-003.

Anderson, G.Q.A., Fergusson, M.J., 2006. Energy from biomass in the UK: sources, processes and biodiversity implications. Ibis 148, 180-183. http://dx.doi.org 10.1111/j.1474-919X.2006.00535.x.

APA, 2014. http://sniamb.apambiente.pt/clc/frm (last accessed on 28.09.14.).

Bélair, C., Ichikawa, K., Wong, B.Y.L., Mulongoy, K.J., 2010. Sustainable Use of Biological Diversity in Socio-ecological Production Landscapes. Background to the 'Satoyama Initiative for the Benefit of Biodiversity and Human Well-Being'. CBD Technical Series No. 52. Secretariat of the Convention on Biological Diversity, Montreal, Canada.

Boukis, I., Vassilakos, N., Karellas, S., Kakaras, E., 2009. Techno-economic analysis of the energy exploitation of biomass residues in Heraklion Prefecture - Crete. Renew. Sustain. Energy Rev. 13 (2), 362-377. http://dx.doi.org/10.1016 j.rser.2007.10.006.

Bringezu, S., Schütz, H., Arnold, K., Merten, F., Kabasci, S., Borelbach, P., Michels, C. Reinhardt, G.A., Rettenmaier, N., 2009. Global implications of biomass and biofuel use in Germany - recent trends and future scenarios for domestic and foreign agricultural land use and resulting GHG emissions. J. Clean. Prod. 17 (Suppl. 1), S57-S68. http://dx.doi.org/10.1016/j.jclepro.2009.03.007.

Cammeraat, L.H., Imeson, A.C., 1999. The evolution and significance of soil-vegetation patterns following land abandonment and fire in Spain. Catena 37 (1), 107-127. http://dx.doi.org/10.1016/S0341-8162(98)00072-1.

Campos, P., Ovando, P., Montero, G., 2008. Does private income support sustainable agroforestry in Spanish dehesa? Land Use Policy 25 (4), 510-522. http:/ dx.doi.org/10.1016/j.landusepol.2007.11.005.

Canteiro, C., Pinto-Cruz, C., Simões, M.P., Gazarini, L., 2011. Conservation of Mediterranean oak woodlands: understory dynamics under different shrub management. Agrofor. Syst. 82 (2), 161-171. http://dx.doi.org/10.1007/s10457-0119375-6.

Carlos, J.S., Corvacho, H., 2010. Retrofit measures in old elementary school buildings towards energy efficiency. J. Civ. Eng. Manag. 16 (4), 567-576. http://dx.doi.org/ 10.3846/jcem.2010.63.

Chalikias, M.S., Kyriakopoulos, G., Kolovos, K.G., 2010. Environmental sustainability and financial feasibility evaluation of woodfuel biomass used for a potential replacement of conventional space heating sources. Part I: a Greek case study. Oper. Res. 10 (1), 43-56. http://dx.doi.org/10.1007/s12351-009-0033-y.

CME, 2008. Conselho local de ação social de Estremoz. Câmara Municipal de Estremoz, Estremoz, Portugal.

CME, 2010. Plano municipal de emergência de Protecção Civil. Protecção Civil de Estremoz, Câmara Municipal de Estremoz, Estremoz, Portugal.

de Wit, M., Faaij, A., 2010. European biomass resource potential and costs. Biomass Bioenergy 34 (2), 188-202. http://dx.doi.org/10.1016/j.biombioe.2009.07.011.

EC, 2010. Communication from the Commission. Europe 2020. A Strategy for Smart Sustainable and Inclusive Growth. $\operatorname{COM}(2010)$ 2020. European Commission, Brussels, Belgium.

EC, 2014. Commission Staff Working Document. State of Play on the Sustainability of Solid and Gaseous Biomass Used for Electricity, Heating and Cooling in the EU. SWD(2014) 259 Final. European Commission, Brussels, Belgium.

EIONET, 2014. http://sia.eionet.europa.eu/CLC2006 (last accessed on 28.09.14.)

Ericsson, K., Nilsson, L., 2006. Assessment of the potential biomass supply in Europe using a resource-focused approach. Biomass Bioenergy 30 (1), 1-15. http:// dx.doi.org/10.1016/j.biombioe.2005.09.001.

Eurostat, 2014. http://epp.eurostat.ec.europa.eu/portal/page/portal/eurostat/home (last accessed on 12.11.14.).

Fernandes, U., Costa, M., 2010. Potential of biomass residues for energy production and utilization in a region of Portugal. Biomass Bioenergy 34 (1), 661-666. http://dx.doi.org/10.1016/j.biombioe.2010.01.009.

Ferreira, S., Moreira, N.A., Monteiro, E., 2009. Bioenergy overview for Portugal Biomass Bioenergy 33 (11), 1567-1576. http://dx.doi.org/10.1016 j.biombioe.2009.07.020.

Franklin, F., 1993. Preserving biodiversity: species, ecosystems, or landscapes? Ecol. Appl. 3 (2), 202-205. http://dx.doi.org/10.2307/1941820.

Gómez, A., Rodrigues, M., Montañés, C., Dopazo, C., Fueyo, N., 2010a. The potential for electricity generation from crop and forestry residues in Spain. Biomass Bioenergy 34 (5), 703-719. http://dx.doi.org/10.1016 j.biombioe.2010.01.013.

Gómez, A., Zubizarreta, J., Rodrigues, M., Dopazo, C., Fueyo, N., 2010b. An estimation of the energy potential of agro-industrial residues in Spain. Resour. Conserv. Recycl. 54 (11), 972-984. http://dx.doi.org/10.1016/j.resconrec.2010.02.004.

González-García, S., Dias, A.C., Clermidy, S., Benoist, A., Maurel, V.B., Gasol, C.M., Gabarell, X., Arroja, L., 2014. Comparative environmental and energy profiles of potential bioenergy production chains in Southern Europe. J. Clean. Prod. 76, 42-54. http://dx.doi.org/10.1016/j.jclepro.2014.04.022.

Harrison, P.A., Berry, P.M., Simpson, G., Haslett, J.R., Blicharska, M., Bucur, M. Dunford, R., Egoh, B., Garcia-Lorente, M., Geamănă, N., Geertsema, W., Lommelen, E., Meiresonne, L., Turkelboom, F., 2014. Linkages between biodiversity attributes and ecosystem services: a systematic review. Ecosyst. Serv. 9, 191-203. http://dx.doi.org/10.1016/j.ecoser.2014.05.006.

ICNF, 2013. http://www.icnf.pt/portal/naturaclas/rn2000/resource/rn-plan-set/hab/ hab-6310 (last accessed on 27.07.13.)

INE, 2011. Censos 2011 - Resultados provisórios. INE, Lisboa, Portugal.

INE, 2012. Anuário estatístico da região do Alentejo 2011. INE, Lisboa, Portugal. 
Jeswani, H.K., Gujba, H., Azapagic, A., 2011. Assessing options for electricity generation from biomass on a life cycle basis: environmental and economic evaluation. Waste Biomass Valoriz. 2 (1), 33-42. http://dx.doi.org/10.1007/s12649-010-9057-z.

Joffre, R., Rambal, S., Ratte, J.P., 1999. The dehesa system of southern Spain and Portugal as a natural ecosystem mimic. J. Agrofor. 45 (1-3), 57-79. http:/ dx.doi.org/10.1023/A:1006259402496.

Lattimore, B., Smith, C.T., Titus, B.D., Stupak, I., Egnell, G., 2009. Environmental factors in woodfuel production: opportunities, risks, and criteria and indicators for sustainable practices. Biomass Bioenergy 33 (10), 1321-1342. http:// dx.doi.org/10.1016/j.biombioe.2009.06.005.

López-Rodríguez, F., Atanet, C.P., Blázquez, F.C., Celma, A.R., 2009. Spatial assessment of the bioenergy potential of forest residues in the western province of Spain, Caceres. Biomass Bioenergy 33 (10), 1358-1366. http://dx.doi.org 10.1016/j.biombioe.2009.05.026.

Lourinho, G., Brito, P., 2015. Assessment of biomass energy potential in a region of Portugal (Alto Alentejo). Energy 81, 189-201. http://dx.doi.org/10.1016/ j.energy.2014.12.021.

Makkonen, M., Huttunen, S., Primmer, E., Repo, A., Hildén, M., 2015. Policy coherence in climate change mitigation: an ecosystem service approach to forests as carbon sinks and bioenergy sources. For. Policy Econ. 50, 153-162. http:// dx.doi.org/10.1016/j.forpol.2014.09.003.

Mallaki, M., Fatehi, R., 2014. Design of a biomass power plant for burning date palm waste to cogenerate electricity and distilled water. Renew. Energy 63, 286-291. http://dx.doi.org/10.1016/j.renene.2013.09.036.

Mani, S., Sokhansanj, S., Tagore, S., Turhollow, A.F., 2010. Techno-economic analysis of using corn stover to supply heat and power to a corn ethanol plant - part 2: cost of heat and power generation systems. Biomass Bioenergy 34 (3), 356-364. http://dx.doi.org/10.1016/j.biombioe.2009.11.007.

MAOTDR, 2006. PROT Algarve. Ministério do Ambiente, do Ordenamento do Território e do Desenvolvimento Regional, Lisboa, Portugal.

Mendes, J.C., Queiroz, D.X., Anastácio, P.A., Gonçalves, M.T., Cardoso, M.R. Coelho, M.G., 1991. Normais Climatológicas da região de "Alentejo e Algarve", correspondentes a 1951-1980. Clima Port. 49 (4), 35-36.

Michopoulos, A., Skoulou, V., Voulgari, V., Tsikaloudaki, A., Kyriakis, N.A., 2014. The exploitation of biomass for building space heating in Greece: energy, environmental and economic considerations. Energy Convers. Manag. 78, 276-285. http://dx.doi.org/10.1016/j.enconman.2013.10.055.

Monforti, F., Bódis, K., Scarlat, N., Dallemand, J.-F., 2013. The possible contribution of agricultural crop residues to renewable energy targets in Europe: a spatially explicit study. Renew. Sustain. Energy Rev. 19, 666-677. http://dx.doi.org/ 10.1016/j.rser.2012.11.060.

Moreira, F., Viedma, O., Arianoutsou, M., Curt, T., Koutsias, N., Rigolot, E., Barbati, A., Corona, P., Vaz, P., Xanthopoulos, G., Mouillot, F., Bilgili, E., 2011. Landscape-wildfire interactions in southern Europe: implications for landscape management. J. Environ. Manag. 92 (10), 2389-2402. http://dx.doi.org/10.1016/ j.jenvman.2011.06.028.
Picchi, G., Silvestri, S., Cristoforetti, A., 2013. Vineyard residues as a fuel for domestic boilers in Trento Province (Italy): comparison to wood chips and means of polluting emissions control. Fuel 113, 43-49. http://dx.doi.org/10.1016/ j.fuel.2013.05.058.

Pinto-Correia, T., Godinho, S., 2013. Changing agriculture - changing landscapes: what is going on in the high valued Montado? In: Ortiz-Miranda, D., MoraguesFaus, A., Arnalte-Alegre, E. (Eds.), Agriculture in Mediterranean Europe: between Old and New Paradigms, Research in Rural Sociology and Development, vol. 19. Emerald Group Publishing Limited, pp. 75-90.

Pinto-Correia, T., Mascarenhas, J., 1999. Contribution to the extensification/intensification debate: new trends in the Portuguese montado. Landsc. Urban Plan. 46 (1-3), 125-131. http://dx.doi.org/10.1016/S0169-2046(99)00036-5.

Pinto-Correia, T., Ribeiro, N., Potes, J.M., 2013. Livro Verde dos Montados. Universidade de Évora, Évora, Portugal.

Plininger, T., Pulido, F.J., Schaich, H., 2004. Effects of land-used and landscape structure on holm oak recruitment and regeneration at farm level in Quercus ilex L. dehesas. J. Arid Environ. 57 (3), 345-364. http://dx.doi.org/10.1016/ S0140-1963(03)00103-4.

RETScreen, 2013. http://www.retscreen.net (last accessed on 01.02.13.)

Rivas-Martínez, S., 1979. Brezales y jarales de Europa occidental (Revisión fitosociológica de las clases Calluno-Ulicetea y Cisto-Lavanduletea). Lazaroa 1, 5-127.

Scarlat, N., Blujdea, V., Dallemand, J.-F., 2011. Assessment of the availability of agricultural and forest residues for bioenergy production in Romania. Biomass Bioenergy 35 (5), 1995-2005. http://dx.doi.org/10.1016/j.biombioe.2011.01.057.

Schimel, D.S., House, J.I., Hibbard, K.A., Bousquet, P., Ciais, P., Peylin, P., Braswell, B.H., Apps, M.J., Baker, D., Bondeau, A., Canadell, J., Churkina, G., Cramer, W., Denning, A.S., Field, C.B., Friedlingstein, P., Goodale, C., Heimann, M., Houghton, R.A., Melillo, J.M., Moore, B., Murdiyarso, D., Noble, I., Pacala, S.W., Prentice, I.C., Raupach, M.R., Rayner, P.J., Scholes, R.J., Steffen, W.L., Wirth, C., 2001. Recent patterns and mechanisms of carbon exchange by terrestrial ecosystems. Nature 414, 169-172. http://dx.doi.org/10.1038/35102500.

Skoulou, V., Zabaniotou, A., 2007. Investigation of agricultural and animal wastes in Greece and their allocation to potential application for energy production. Renew. Sustain. Energy Rev. 11 (8), 1698-1719. http://dx.doi.org/10.1016/ j.rser.2005.12.011.

Verkerk, P.J., Mavsar, R., Giergiczny, M., Lindner, M., Edwards, D., Schelhaas, M.J., 2014. Assessing impacts of intensified biomass production and biodiversity protection on ecosystem services provided by European forests. Ecosyst. Serv. 9, 155-165. http://dx.doi.org/10.1016/j.ecoser.2014.06.004.

Viana, H., Cohen, W.B., Lopes, D., Aranha, J., 2010. Assessment of forest biomass for use as energy. GIS-based analysis of geographical availability and locations of wood-fired power plants in Portugal. Appl. Energy 87, 2551-2560. http:// dx.doi.org/10.1016/j.apenergy.2010.02.007.

Vieira, A., Franco, C., Marques, F., Rosa, F., Monsanto, M., 2006. Avaliação do potencial de biomassa da região do Algarve. INETI, Lisboa, Portugal. 